\title{
Feeding by Chaetognatha: Energy Balance and Importance of Various Components of the Diet of Sagitta elegans
}

\author{
Sifford Pearre, Jr. \\ Department of Oceanography, Dalhousie University, Halifax, Nova Scotia B3H 4J1, Canada
}

\begin{abstract}
Daily rations, in terms of number and energy content of food items, were estimated for three developmental stages of Sagitta elegans Verrill in Bedford Basin, Nova Scotia (Canada) at two times of year, and compared to estimated energy requirements. In mid July, the younger two stages appeared to be meeting their metabolic needs but the oldest stage did not. This corresponded to a major annual period of spawning and disappearance of mature S. elegans. The opposite seemed to be the case in December, which was not a spawning period: while the older two stages appeared to be obtaining sufficient energy, the youngest stage seemed to experience a substantial deficit. Population data for the following 3 years implies that the youngest individuals suffered very high losses during this period. The previously noted simplicity of the chaetognath's population cycle in Bedford Basin may be due in part to such an annual loss of individuals hatched late in the season. While copepods were always numerically dominant among prey items, tintinnids and rotifers were important in the diets of small individuals in July, and cannibalism played an important part in the energy intake of the larger stages in December
\end{abstract}

\section{INTRODUCTION}

Most interest in feeding energetics of marine plankton has so far focused on copepods (Steele and Mullin, 1977; Conover, 1978). However, in order to fully comprehend marine food chains we must extend our examination to other links, both higher and lower.

The chaetognath Sagitta elegans Verrill has been implicated as a controlling predator of copepods in areas where it is abundant. Bigelow (1924) considered it to be the major predator of planktonic herbivores in the Gulf of Maine. In Bedford Basin, Nova Scotia (Canada) - the area of this study - Sameoto (1973) estimated that the production of $S$. elegans was almost $30 \mathrm{Kcal} \mathrm{m} \mathrm{K}^{-2} \mathrm{y}^{-1}$, and that, if copepods were the only food source, it would consume over a third of their annual production. Unfortunately, most chaetognath species have proven rather intractable laboratory animals, and so feeding information is mainly based on field data. Conversion of these data to energy budgets requires correlative field and laboratory studies and a number of assumptions, but appears to be the only way to begin.

Feigenbaum (MS 1979) has examined the relationship of rations to respiratory demand of Sagitta elegans in Vinyard Sound, Massachusetts (USA), in February and March. In this paper I examine the rations of $S$. elegans in Bedford Basin in two seasons, using a modified version of Feigenbaum's methodology. The basic scheme of this consists of: (1) Estimation of the mean energy content of prey of each type in each of 3 maturity stages of Sagitta; (2) conversion of these data to the daily ration of energy supplied by each prey type per cubic meter of water; (3) summation of the total daily rations for each developmental stage on each sampling date; (4) comparison of estimated daily energy intake to estimated respiratory energy demand per stage and date; (5) comparison of the estimated mean energy surplus or deficit for each stage with that stage's expected trend of abundance at each time of year, using additional field information gathered in the following 3 years by Zo $(1969,1973)$ and Sameoto $(1971 \mathrm{a}$, 1973). 


\section{MATERIALS AND METHODS}

\section{Collection and Examination}

Zooplankton was collected on July $17-18$ and December 12-13, 1967 at a station near the center of Bedford Basin, Halifax Harbor, Nova Scotia by horizontal tows of a $12.7 \mathrm{~cm}$ diameter Clarke-Bumpus closing net fitted with $0.239 \mathrm{~mm}$ mesh nets (Pearre, 1973). Seven depths were sampled; in the July series collecting was done at 7 times during $24 \mathrm{~h}$, while in December 5 , sample sets were made. In each tow the nets were open for $4 \mathrm{~min}$ and filtered $1.5-2 \mathrm{~m}^{3}$ of water. Immediately upon retrieval, samples were preserved with buffered formalin. One eighth of each of the July samples was examined and whole samples were examined in December. Chaetognaths were removed from the samples, measured and assigned to stages based on Dunbar's (1962) and McLaren's (1969) classification system ( $\mathrm{I}=$ no visible ovary, II = some ovary but no mature eggs, III = one or more mature eggs). All specimens which had opaque regions in the gut indicating possible food remains - were removed and examined microscopically. In larger specimens this was done by dissection; small specimens were occasionally whole mounted. Prey were identified in as much detail as possible.

\section{Prey Data Transformation and Processing}

All counts of prey and predators were expressed in terms of unit volumes of water sampled $\left(\mathrm{m}^{3}\right)$, in order to make sample data additive. The number of prey and any type found in the chaetognaths was converted to a daily ration following the equation suggested by Bajkov (1935) for fish, and used by a number of workers for chaetognaths (Feigenbaum, 1979)

$$
R=N_{H} \quad \underline{24}
$$

where $N_{H}=$ number of prey found in gut; $t=$ digestion (gut-clearance) time in $h$.

Digestion time in chaetognaths is temperature dependent (Mironov, 1960; Feigenbaum, MS 1979), and was found to be adequately described by the relationship

$$
t=0.098 e^{-0.095 T^{v}}
$$

where $t=$ digestion time $(h)$ and $T^{\circ}=$ temperature $\left({ }^{\circ} \mathrm{C}\right)$. (For derivation of the equation see Appendix). Digestion time in chaetognaths appears to be relatively independent of chaetognath size or type of food (Kuhlmann, 1976; Szyper, 1978; Feigenbaum MS, 1979; Sullivan, 1980). To determine mean digestion time it was necessary to estimate the mean temperature experienced by each developmental stage during the time periods of sampling by computing a mean depth for each stage over the 24 -h period and estimating a temperature corresponding to this depth by linear interpolation from Krauel's (1969) temperature profile data for these dates.

The major types of prey found (Pearre, 1973) were classified into eight categories: (1) Copepods (adults and copepodites); (2) copepod nauplii; (3) chaetognaths; (4) polychaete larvae; (5) tintinnids; (6) rotifers; (7) cladocerans; (8) 'unidentified prey', usually too much digested to retain identifiable hard parts. Several different methods were employed to obtain biomass estimates for each prey type.

(1) Mean body widths of copepod prey as a function of chaetognath predator size were determined separately for the July and December sample sets by equations derived in Pearre (1980a; Table 1). These were transformed to wet weights by Eqation 1-C. Dry weights (1-D) were obtained by a regression on data from Nakai (1955) and Omori (1969) on mainly the same species (Fig. 1). Ash weights (1-E) were determined from data by a number of authors using the regression of Figure 2. Laurence (1976) supplied data on calories per milligram ash-free dry weight of the principal copepod species in summer. For the com-

\begin{tabular}{|c|c|c|c|c|}
\hline Eq. No. & Equation & $n$ & $r^{2}$ & Reference or data source \\
\hline $1-A$ & $=0.333 P^{0.507}$ & & & Pearre (1980a), July \\
\hline $1-B$ & $H=0.296 P^{0.452}$ & & & Pearre (1980a), December \\
\hline $1-\mathrm{C}$ & $W_{W}=1.557 H^{2.878}$ & & & Pearre $(1980 \mathrm{~b})$ \\
\hline $1-\mathrm{D}$ & $W_{D}=0.154 W_{W}^{1.075}$ & 31 & $0.981 \cdots$ & Nakai (1955), Omori (1969) \\
\hline $1-E$ & $W_{A}=0.0303 W_{D}^{0.832}$ & 59 & $0.959 \cdots$ & $\begin{array}{l}\text { Orr (1934), Nakai (1955), Omorı (1969, 1970), } \\
\text { Razouls (1977), Bămstedt (1978) }\end{array}$ \\
\hline $1-\mathrm{F}$ & $W_{F}=W_{D}-W_{A}$ & & & \\
\hline \multicolumn{4}{|c|}{$\begin{array}{l}H=\text { copepod prey body width, } \mathrm{mm}_{;} P=\text { chaetognath predator } \\
\text { head width, mm; } W_{W}=\text { wet weight, } \mathrm{mg} ; W_{D}=\text { dry weight, } \mathrm{mg}\end{array}$} & $\begin{array}{l}W_{A}=\text { ash welght, } m g ; W_{F}=\text { ash-free dry weight, mg; } \\
\therefore \equiv p<0.001 \text { (Sokal and Rohlf, 1969) }\end{array}$ \\
\hline
\end{tabular}

Table 1. Estimation of weight values of copepod prey 


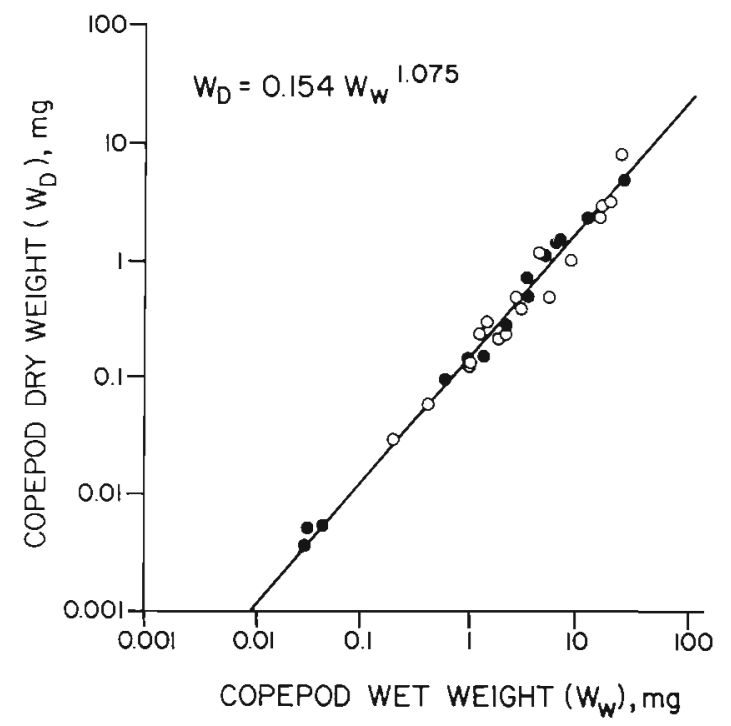

Fig. 1. Relation of dry weight to live wet weight for copepods and copepodids of different sizes. from Nakai (1955); ofrom Omori (1969)

munity found in Bedford Basin, this averaged $5.53 \mathrm{cal}$ $\mathrm{mg}^{-1}$. The December value was taken as $6.80 \mathrm{cal}$ $\mathrm{mg}^{-1}$, obtained by multiplying Laurence's values by the ratio of winter to summer values for samples consisting mainly of copepods from St. Margaret's Bay, N.S. (Platt and Irwin, 1968).

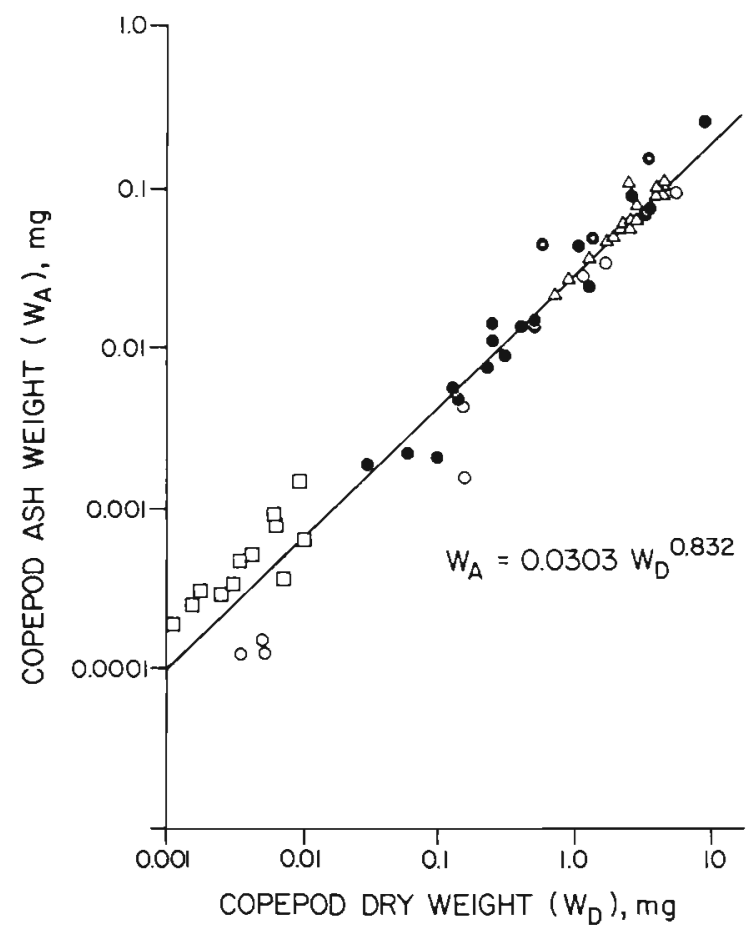

Fig. 2. Relation of ash weight to dry weight for copepods and copepodids of different sizes. $\square$ from Razouls (1977); $\bullet$ from Omori (1969); $\triangle$ from Omori (1970); Ofrom Nakai (1955); o from Båmstedt (1978) and Orr (1934)
(2) Copepod nauplii were not common as food, except in Stage I. They were assumed to be equivalent to Acartia clausi naupliar Stage $V$ with a dry weight of $0.00034 \mathrm{mg}$ (Durbin and Durbin, 1978) and converted to calories as in the preceding section.

(3) Chaetognath chaetae are resistant to digestion and proportional to the size of the individual bearing them (Fig. 3, Table 2). Because there is only one species in Bedford Basin, prey size could be estimated by measurement of the chaetae (Pearre, 1970). This was done separately for July (Fig. 4, Eq. 2-B) and December (Fig. 5, Eq. 2-C). Dry weight was determined from Equation 2-D, based on the equations of Matthews and Hestad (1977) and Feigenbaum (MS 1979) which are very similar. Wet weight (Eq. 2-E) was determined by substitution of Sameoto's (1971 b) equation for wet weight vs length into his equation for dry weight vs length. Calorific values were determined by multiplication of mean dry weight values by $4.0 \mathrm{Kcal}$ $\mathrm{g}^{-1}$ for small prey, mainly Station I, in predator Stages $1,4.3 \mathrm{Kcal} \mathrm{g}^{-1}$ in predator State II, and $4.7 \mathrm{Kcal} \mathrm{g}^{-1}$ for larger prey, mainly Station II, in predator Stage III. (Sameoto, 1971 b).

(4) Prey polychaete larvae were indentified from setae only; neither species nor size could be determined. Wet weights were assumed from values given by Mironov (1960) for prey for Sagitta setosa and $S$. euxina in the Black Sea, and values for planktonic larval stages in general given by Lubny-Gertsyk (1953) and Petipa (1957). The prey of S. elegans St.I were assumed to weigh $0.01 \mathrm{mg}$, of St.II, $0.03 \mathrm{mg}$, and of St.III, $0.05 \mathrm{mg}$. Dry weights were estimated as: $W_{D}=$ $0.20 W_{w}$ (Tyler, 1973) and an energy content of $5.7 \mathrm{cal}$ $\mathrm{mg}^{-1}$ was taken from the data of Ostapenya and Shushkina (1971).

(5) Tintinnids, identified from the digestion-resistant loricae by M. Paranjape, were very important in the diets of the youngest Sagitta elegans and occasionally found even in St.II in December. Overall, however, their contribution even to the nutrition of St.I was modest. Wet weight was taken as $0.006 \mathrm{mg}$ (M. Paranjape, pers. comm.) and dry weight calculated from Johansen (1976) as: $\mathrm{W}_{\mathrm{D}}=0.13 \mathrm{~W}_{\mathrm{w}}$. A value of $5.5 \mathrm{cal}$ $\mathrm{mg}^{-1}$ was assumed.

(6) Rotifers were found in the guts of St.I Sagitta elegans in July (identified by G. Deevey). A wet weight of $0.0025 \mathrm{mg}$ was assumed from data of Petipa (1957) and Studenikina and Cherepakhina (1969). Harding et al. (1980) have made mass wet and dryweight determinations on size-sorted zooplankton samples from St. Georges Bay, N.S. Geometric-mean (G.M.) regressions were calculated for the dependence of wet weight on dry weight (sample size) for each size class. These data refer to the weight relationships of whole plankton samples rather than individual ani- 
Table 2. Estimation of weight values of chaetognath prey

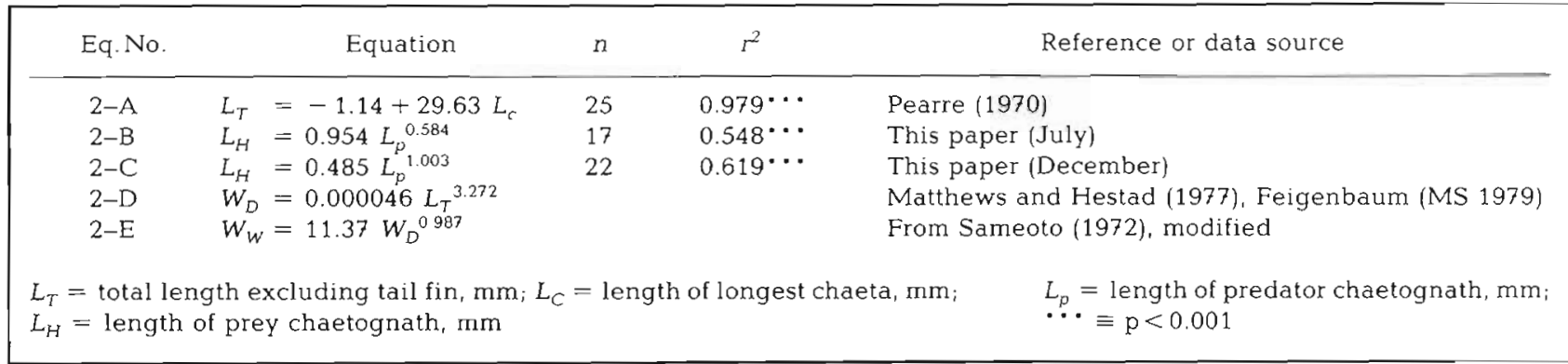

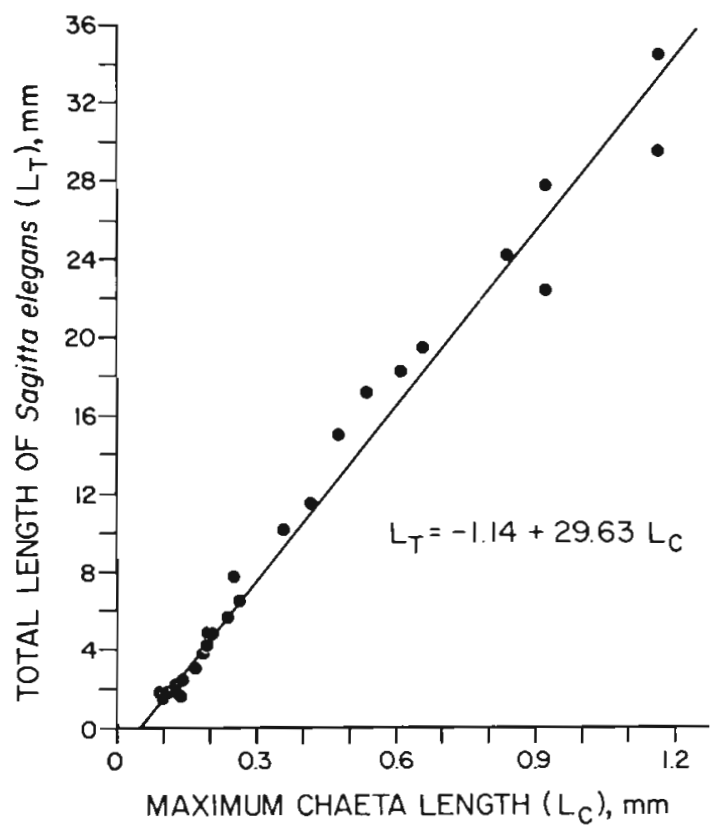

Fig. 3. Sagitta elegans. Total length (tip of head to base of tail excluding tail fin) vs length of longest chaeta (grasping spine)

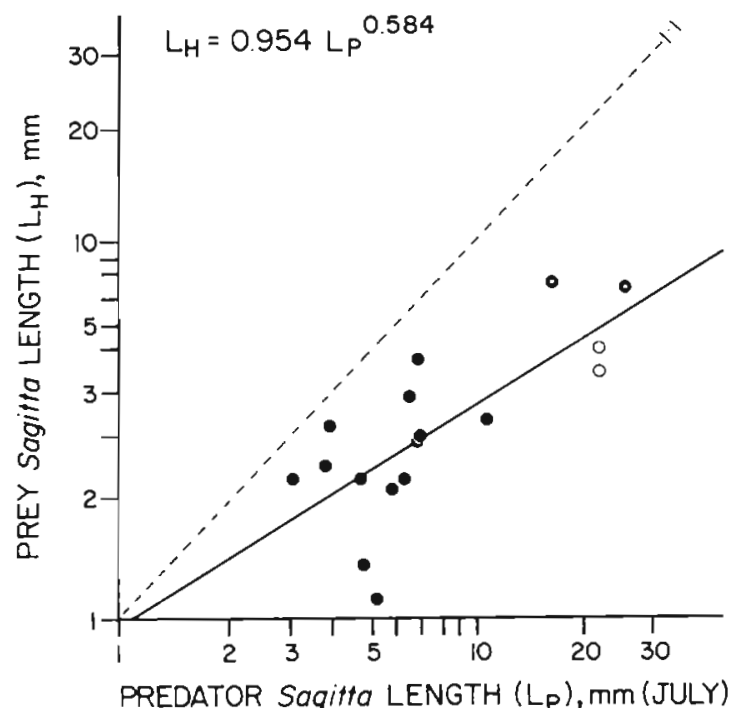

Fig. 4. Sagitta elegans. Prey (cannibalized) chaetognath length vs predator length. Bedford Basin, July. (After Pearre, 1970). - predator Stage I; O predator Stage II; O predator Stage III

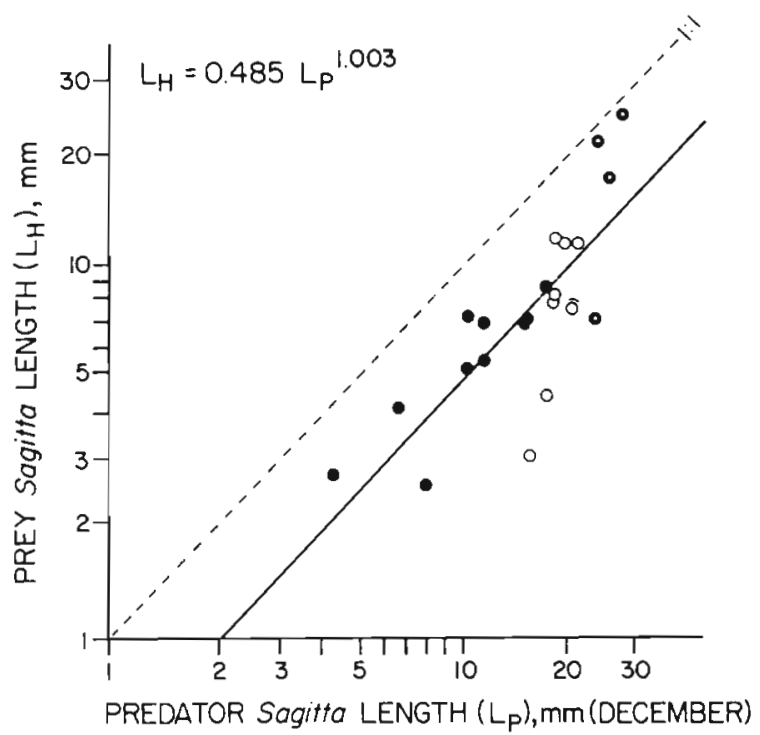

Fig. 5. Sagitta elegans. Prey (cannibalized) chaetognath length vs predator length. Bedford Basin, December (After Pearre, 1970). - predator Stage $I_{i} O$ predator Stage $I_{i}$ o predator Stage III

mals, but have the advantage over those of Wiebe et al. (1975) of being separated into fractions characteristic of different species. For the size class in which rotifers generally occurred, this relationship was: $W_{D}=0.128$ $W_{w} 0.848$

(7) Cladocera were also rare in the diet and found only in St.I. They were not identified to species but Bedford Basin contains three common species of which Podon leuckarti is probably dominant in July, and Evadne nordmanni in late fall (D. Gifford, pers. comm.). Wet weights, dry weights, and calorific values for these species were taken from Pavlova (1967).

(8) 'Unidentified prey' were assumed to be of copepod size and mean composition, and all ration parameters were estimated as for copepods.

\section{Energy Needed for Respiration}

Mean temperatures experienced by each stage of Sagitta elegans on each sampling day were calculated 
Table 3. Sagitta elegans. Computation of chaetognath respiration in Bedford Basin, 1967

\begin{tabular}{|c|c|c|c|c|c|c|}
\hline \multirow[t]{2}{*}{ Date } & \multirow[t]{2}{*}{ Stage } & \multirow{2}{*}{$\begin{array}{c}\text { Mean } \\
\text { depth, m }\end{array}$} & \multirow{2}{*}{$\begin{array}{c}\text { Mean } \\
\text { temp. }{ }^{\circ} \mathrm{C}\end{array}$} & \multicolumn{3}{|c|}{ Match with Sameoto's (1972) regressions } \\
\hline & & & & Month & $\mathrm{T}^{\circ} \mathrm{C}$ & Regressions \\
\hline \multirow[t]{3}{*}{ July } & I & 13.2 & 6.4 & June & 6 & $\mathrm{RR}=4.40 \mathrm{~W}_{\mathrm{w}}^{0.71}$ \\
\hline & II & 29.5 & 2.8 & August & 4 & $\mathrm{RR}=3.09 \mathrm{~W}_{\mathrm{w}}^{0.71}$ \\
\hline & III & 51.4 & 1.7 & May & 1.5 & $R R=3.67 W_{w}{ }^{0.56}$ \\
\hline \multirow[t]{3}{*}{ December } & I & 21.7 & 4.9 & November and December $\left({ }^{\circ}\right)$ & 4 & $\mathrm{RR}=4.34 \mathrm{~W}_{\mathrm{w}}^{0.53}$ \\
\hline & II & 47.6 & 4.6 & November and December $\left({ }^{\circ}\right)$ & 4 & $\mathrm{RR}=4.34 \mathrm{~W}_{w}^{0.53}$ \\
\hline & III & 56.7 & 4.8 & November and December $\left({ }^{\prime}\right)$ & 4 & $\mathrm{RR}=4.34 \mathrm{~W}_{\mathrm{w}}^{0.53}$ \\
\hline \multicolumn{7}{|c|}{ ( $)$ Combined as a single regression; with $n=34, r^{2}=0.712 \cdots$} \\
\hline \multicolumn{7}{|c|}{$\mathrm{RR}=$ respiration rate, $\mu \mathrm{l} \mathrm{O}_{2} 24 \mathrm{~h}^{-1}$} \\
\hline \multicolumn{7}{|c|}{$W_{w}=$ wet weight, $\mathrm{mg}$} \\
\hline
\end{tabular}

from mean depths on each date (Pearre, 1970) and the temperature/depth structure (Krauel, 1969). Sameoto (1972) estimated respiration rates of $S$. elegans as functions of size at various temperatures in different seasons. These regressions were matched as nearly as possible with the seasons and temperatures found (Table 3). Caloric requirement per day $\left(\mathrm{CR}_{24}\right)$ was calculated from the caloric equivalent of the respiration rate and the assimilation rate from Sameoto (1972) as $\mathrm{CR}_{24}=0.0048 \mathrm{RR}_{24} / \mathrm{AR}=0.0067 \mathrm{RR}_{24}$ where $\mathrm{RR}$ equals the respiration rate in calories and $A R$ the percentage assimilation (72). This figure can be compared to the total caloric intake to determine if the chaetognaths had, on average, ingested sufficient energy to meet respiratory demands.

The relationships used in estimating the various parameters derive to a large extent from different organisms and areas, and few of the constants found in the literature had attached confidence intervals. I believe that it is illusory to attempt to define significances or confidence intervals for the overall results, and it is likely that close matches of energy intake to respiratory demand are fortuitous. However, if the assumptions are basically correct and internally consistent then inter-stage and inter-season comparisons should show trends which do correspond with expectations.

\section{RESULTS}

In both seasons small Sagitta elegans were numerically dominant, and as shown by Zo $(1969,1973)$ and Sameoto (1973), a strong bimodality in the size distributions is apparent (Figs 6 and 7). In July, the mature (Stage III) individuals actually outnumbered the intermediate stage, though in December, which was not a major spawning period, some $S$. elegans which were large enough to spawn appear to have remained in Stage II. Note that in December the abundance peak

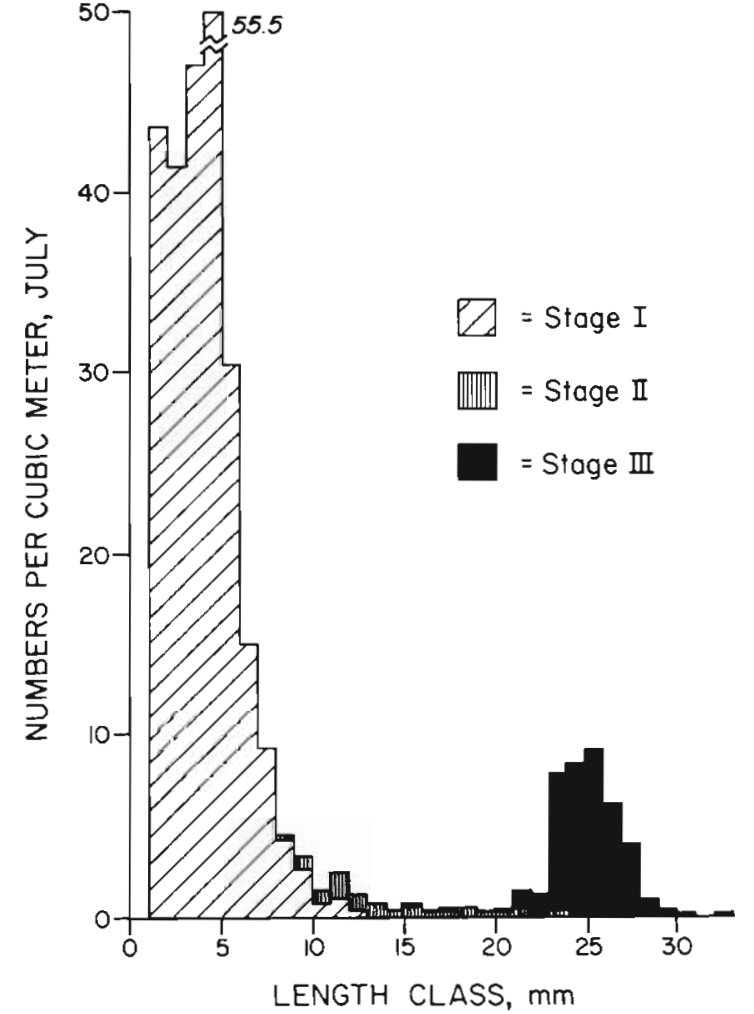

Fig. 6. Sagitta elegans. Population structure in Bedford, Basin, July $17-18,1967$

for Stage I is at a larger size than in July. This can be also seen from the mean sizes of this stage in Table 4. At both times, the specific energy needs for respiration are highest in the small stages. Copepodids and adult copepods are dominant in all groups in both July and December (Table 5). However, the actual importance of each component in the diets of the chaetognaths depends more on biomass or energy content than on numbers.

As shown in Table 6, food intake is usually surprisingly close to the calculated requirements, the most obvious deficits occurring in Stage III in July and Stage I in December. However, because these data are aver- 


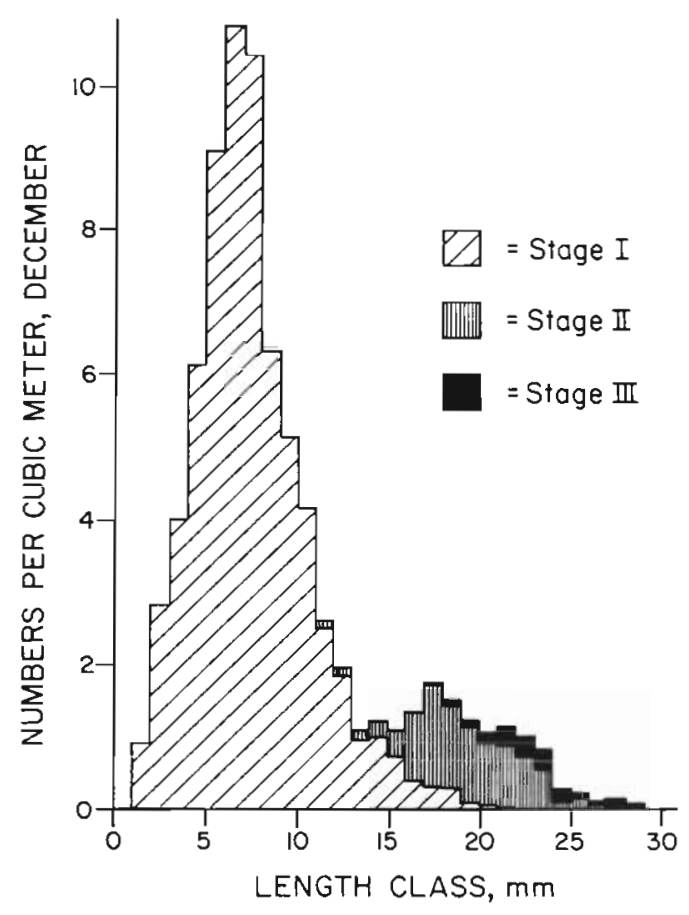

Fig. 7. Sagitta elegans. Population structure in Bedford Basin, December $12-13,1967$. Note change of vertical scale

aged over whole subgroups of individuals while in nature resources probably are not shared evenly, some members of each subgroup probably exceed their minimum requirements while others are starving. Nonrandomness of prey distributions within the sampled chaetognath populations, as measured by Lloyd's index of patchiness (Pielou, 1969), was 4.9 in July and 11.2 in December, both highly significant.

In July, the principal contributors to the energy budget were copepods and polychaete larvae, although tintinnids and rotifers were very important for Stage $I_{i}$ in fact, the chief food items found in the smallest chaetognaths (up to about $4 \mathrm{~mm}$ ) were tintinnids. Although these may be overestimated because of digestion-resistant loricae (Pearre, 1973), non-loricate ciliates may have been at least equally underestimated.

Cannibalism became much more important in each size class in December and contributed about as much energy as copepods in Stage III. Cannibalism is considered a valuable adaptive strategy in a seasonally food-limited environment (Fox, 1975). The increased contribution of cannibalism to the larger stages depended more on increased mean prey size (Figs 4 and 5) than on greater numerical proportion of chaetognath prey. This appears to be the consequence of an increase in mean hunting time in deep water, which means more exposure to large potential prey (Pearre, 1970).

The energy budget in Table 6 was computed for the whole population. Specific rations (Table 7 ) are derived by dividing the mean values of total prey by the corresponding mean value for the predators. As expected, larger predators eat more prey, but specific rations tend to decrease with predator size in July. The December data appear distorted by the very low amount of feeding by Stage I and the anomalously high feeding by the less abundant Stage III. Reeve (1980) has recently demonstrated that digestion time in Sagitta hispida is a function of age. If true for $S$. elegans, this would effectively decrease the estimated rations of the larger individuals relative to the small. This would increase the energy deficit of St.III in July and decrease the energy surplus of St.III in December.

\section{DISCUSSION}

In July, the younger stages appear to have acquired approximately enough energy to meet respiratory demands. Whether sufficient energy is allowed for growth depends on the relative magnitude of demands for excretion, vertical migration, prey catching, etc., as well as on the unknown limits of error of the estimates.

Table 4. Sagitta elegans. Estimated population parameters in Bedford Basin, 1967

\begin{tabular}{|c|c|c|c|c|c|c|}
\hline \multirow[b]{2}{*}{ S. elegans stage: } & \multicolumn{3}{|c|}{ July $17-18$} & \multicolumn{3}{|c|}{ December $12-13$} \\
\hline & I & II & III & I & II & III \\
\hline Abundance numbers $\mathrm{m}^{-3}$ & 216.8 & 7.39 & 38.2 & 64.7 & 9.62 & 1.68 \\
\hline Mean length, mm & 4.03 & 15.0 & 25.0 & 6.77 & 18.9 & 22.9 \\
\hline Mean head width, mm & 0.21 & 0.78 & 1.29 & 0.35 & 0.98 & 1.19 \\
\hline Mean wet weight, mg & 0.051 & 3.70 & 19.6 & 0.28 & 7.87 & 14.7 \\
\hline Mean dry weight, $\mathrm{mg}$ & 0.0046 & 0.33 & 1.77 & 0.025 & 0.71 & 1.33 \\
\hline Mean digestion time, $h$ & 5.6 & 7.8 & 8.7 & 6.4 & 6.6 & 6.5 \\
\hline Mean respiration, $\mu \mathrm{IO}_{2} 24 \mathrm{~h}^{-1}$ & 0.53 & 7.82 & 19.43 & 2.19 & 12.95 & 18.06 \\
\hline Mean energy content, cal. & 0.018 & 1,57 & 8.86 & 0.100 & 3.34 & 6.66 \\
\hline \multicolumn{7}{|l|}{ Mean energy-specific respiration } \\
\hline $\mathrm{Cal} / 24^{-1}$ cal. content ${ }^{-1}$ & 0.141 & 0.024 & 0.011 & 0.105 & 0.019 & 0.013 \\
\hline
\end{tabular}


Table 5. Sagitta elegans. Numbers of prey of various groups found in guts of chaetognaths, per cubic meter

\begin{tabular}{|c|c|c|c|c|c|c|}
\hline \multirow{2}{*}{$\begin{array}{l}\text { Total volume sampled, } \mathrm{m}^{3} \\
\text { S. elegans stage: }\end{array}$} & \multicolumn{3}{|c|}{$\begin{array}{c}\text { July } 17-18,1967 \\
76.6\end{array}$} & \multicolumn{3}{|c|}{$\begin{array}{c}\text { Dec. } 12-13,1967 \\
52.1\end{array}$} \\
\hline & I & II & III & 1 & II & III \\
\hline \multicolumn{7}{|l|}{ Prey } \\
\hline copepodids and adults & 26.2 & 3.13 & 15.7 & 6.13 & 5.37 & 0.94 \\
\hline copepod nauplii & 6.04 & 0 & 0 & 0.13 & 0 & 0 \\
\hline chaetognaths & 1.46 & 0.21 & 0.34 & 0.17 & 0.18 & 0.077 \\
\hline polychaete larvae & 0.46 & 0 & 2.71 & 0 & 0.71 & 0.017 \\
\hline tintinnios & 6.31 & 0 & 0 & 0.61 & 0.024 & 0 \\
\hline rotifers & 5.76 & 0 & 0 & 0 & 0 & 0 \\
\hline cladocerans & 0.36 & 0 & 0 & 0.016 & 0 & 0 \\
\hline unidentified & 3.12 & 1.03 & 2.86 & 0.54 & 0.21 & 0.03 \\
\hline
\end{tabular}

Table 6. Sagitta elegans. Energy budgets for population in Bedford Basin, calories $\mathrm{m}^{-3} \mathrm{~d}^{-1}$

\begin{tabular}{|c|c|c|c|c|c|c|}
\hline \multirow[b]{2}{*}{ S. elegans stage: } & \multicolumn{3}{|c|}{ July $17-18,1967$} & \multicolumn{3}{|c|}{ Dec. $12-13,1967$} \\
\hline & I & II & III & I & II & III \\
\hline \multicolumn{7}{|l|}{ Prey } \\
\hline copepodids and adults & 0.388 & 0.333 & 2.712 & 0.188 & 0.681 & 0.159 \\
\hline copepod nauplii & 0.043 & 0 & 0 & 0.001 & 0 & 0 \\
\hline chaetognaths & 0.015 & 0.020 & 0.085 & 0.006 & 0.184 & 0.175 \\
\hline polychaete larvae & 0.022 & 0 & 0.425 & 0 & 0.009 & 0.036 \\
\hline tintinnids & 0.117 & 0 & 0 & 0.010 & 0.0004 & 0 \\
\hline rotifers & 0.109 & 0 & 0 & 0 & 0 & 0 \\
\hline cladocerans & 0.016 & 0 & 0 & 0.001 & 0 & 0 \\
\hline unidentified & 0.047 & 0.090 & 0.500 & 0.016 & 0.026 & 0.005 \\
\hline Total & 0.757 & 0.443 & 3.722 & 0.222 & 0.900 & 0.375 \\
\hline respiratory demand & 0.765 & 0.386 & 4.949 & 0.946 & 0.831 & 0.202 \\
\hline Diet/demand & 0.99 & 1.15 & 0.75 & 0.23 & 1.08 & 1.85 \\
\hline
\end{tabular}

Table 7 Sagitta elegans. Mean specıfıc diets of each maturity stage in each season

\begin{tabular}{|c|c|c|c|c|c|c|}
\hline \multirow[b]{2}{*}{ S. elegans stage: } & \multicolumn{3}{|c|}{ July $17-18,1967$} & \multicolumn{3}{|c|}{ Dec. $12-13,1967$} \\
\hline & I & II & III & 1 & II & III \\
\hline Mean predator length, mm & 4.03 & 15.0 & 25.0 & 6.77 & 9.62 & 22.9 \\
\hline Mean number of prey per predator & 0.98 & 2.10 & $1.54^{\circ}$ & $0.44^{\circ}$ & 2.21 & 2.68 \\
\hline Dry weight prey/dry weight predator & 0.15 & 0.035 & $0.011^{\circ}$ & $0.023^{\circ}$ & 0.023 & 0.031 \\
\hline Calorific value prey/calorific value predator & 0.19 & 0.038 & $0.011^{\circ}$ & $0.034^{\circ}$ & 0.028 & 0.034 \\
\hline
\end{tabular}

Zo (1969, 1973) and Sameoto (1973) recorded high summer production rates in 1968 and 1969 respectively. The population structure found at this time (Fig. 6) resembles that of $\mathrm{ZO}^{\circ}$ 's data for late June or early July (Zo, 1973; his Fig. 2). Both of these authors found that early summer was a major spawning peak and that most of the large St.III Sagitta elegans, which are semelparous spawners, disappeared shortly afterwards. The low estimate of mean food intake (Tables 6 and 7) probably reflects the inclusion of individuals which have neared the end of their life cycle and ceased feeding altogether.
The December data, on the other hand, appear to show that the larger two stages obtained sufficient food for respiratory needs but that the Stage I individuals experienced a serious deficit. The abundance data show that the smallest specimens (below $6-7 \mathrm{~mm}$ ) are missing in December (Fig. 7). Interestingly, Zo's data reveal a drastic decline in abundance of small Stage I Sagitta elegans between mid December 1968 and mid January 1969. Sameoto's data (Sameoto, 1973; his Fig. 6) appear to confirm this, with virtually complete disappearance of the smallest population mode between December 23, 1969 and January 20, 1970, and a $90 \%$ 
reduction in the height of the smallest-size mode present between December 9, 1970 and January 7, 1971

Zo $(1969,1973)$ and Sameoto (1973) found only two principal generations (spring and fall) in Bedford Basin, in contrast to the much more complicated cycle in nearby St. Margaret's Bay (Sameoto, $1971 \mathrm{~b}$ ). Sameoto suggested that exchange mixed oceanic subpopulations with the native ones in St. Margaret's Bay. Even so, the smallest size group in St. Margaret's Bay seems to have disappeared between early December 1969 and January 1970 (Sameoto, 1971 b; his Fig. 3), a pattern similar to that in Bedford Basin. In Bedford Basin, however, despite a strong fall spawning pulse which continued into December $(Z 0,1969,1973)$ this loss cannot be replaced by exchange, so that the spring spawners would be mainly animals hatched in late summer or early fall. This annual loss of late fall production could account for the simplicity of the pattern of the population cycle in Bedford Basin noted by Sameoto (1973).

Why this period should be so critical probably involves a combination of effects of the physical and biological environments. Sullivan (1980) suggests that 'development of larval chaetognaths depends on abundant, small prey', and the small food organisms in Bedford Basin are at much reduced levels by December (Atherton, 1979; Mayzaud and Taguchi, 1979; Paranjape, 1980). Although food has declined, the water has remained warm enough to cause relatively high respiratory energy demands and specific respiration is highest in the smallest stages (Table 4). A sharp decrease in mean temperature occurs in January (Sameoto, 1973) and from both Zo's and Sameoto's data, it appears that Stage I Sagitta elegans survived well after this time. Feigenbaum (MS 1979) found that small $S$. elegans more than met respiratory demands in February/March at $0^{\circ} \mathrm{C}$ off Woods Hole, Mass. Calculation of the respiration needs of the December Stage I population in Bedford Basin indicates that at $0{ }^{\circ} \mathrm{C}$ the food intake found in this study would have met about $75 \%$ of respiratory needs, instead of the $23 \%$ calculated at $4{ }^{\circ} \mathrm{C}$.

Pearre $(1980$ a) found that the copepods available in Bedford Basin were too small for optimal prey size selection by large Sagitta elegans. This factor combined with declining abundances of all copepods seems to have meant that, in December, large $S$, elegans were unable to meet energy requirements on copepods alone but relied on cannibalism to make up the difference.

\section{CONCLUSIONS}

Although incorporating many assumptions, calculations of energy ingested by various stages of Sagitta elegans in Bedford Basin agree remarkably well with predictions based on respiratory requirements. The two stages found to have fallen furthest short of meeting respiratory requirements (July St.III and December St.I) appear from population surveys to have both been subject to heavy mortality. Thus the approach appears to be potentially useful in population forecasting.

\section{APPENDIX}

Derivation of equation relating digestion time to temperature in Sagitta elegans.

(a) Fänge and Grove (1979) provide a summary of data on the relationship of digestion time to temperature in fish. Two other data sets were obtained from Battle (1934) and Jobling and Davies (1979). I calculated regressions of 4 models (linear, exponential, power curve, and logarithmic) on each of these which consisted of observations at 3 or more temperatures (21 sets). No single model best fit all data sets, but the exponential regression yielded a set of slopes with least variance, and was the best fit to the only data set with more than 5 temperatures (Battle, 1934), or $t_{D}=a$ $e^{-b T}$, with $t_{D}=$ digestion time $(\mathrm{h}) ; T=$ temperature $\left({ }^{\circ} \mathrm{C}\right) ; b=0.0958 \pm 0.0143(95 \%$ confidence limits). On this basis, the relation in Sagitta elegans was assumed to be exponential.

(b) Two determinations of digestion time for Sagitta elegans were available: (1) $t_{D}=2.45 \mathrm{~h}, T=15^{\circ} \mathrm{C}$ (Kuhlmann, 1976); (2) $t_{D}=10.24 \mathrm{~h}, T=0{ }^{\circ} \mathrm{C}$ (Feigenbaum, MS 1979).

Since an exponential curve is determined by two parameters, it can be solved directly from these two points, and gave

$$
t_{D}=0.0977 e^{-0.0953 r}
$$

The remarkable similarity in the $b$ values provides confidence that this is a physiologically reasonable model.

Acknowledgements. I would like to thank S. R. Kerr, J. A. Koslow, D. D. Sameoto, and especially R. J. Conover for critical reviews of this manuscript and many helpful suggestions. The initial data were collected as part of a thesis research project funded by grants from the National Research Council of Canada and grant G.B.4676 from the National Science Foundation (USA) to $C$. M. Boyd. A grant to the author from the Chesapeake Bay Foundation provided partial support for the present study based on these data and support for preparation of the manuscript.

\section{LITERATURE CITED}

Atherton, W. C. (1979). An annual study of the vertical migration patterns of zooplankton in Bedford Basin, Nova Scotia. M. Sc. thesis, Dalhousie Univ., Canada 
Bajkov, A. D. (1935). How to estimate the daily natural food consumption of fish under natural conditions. Trans. Am. Fish. Soc. 65: 288-289

Bamstedt, U. (1978). Studies on the deep-water pelagic community of Korsfjorden, western Norway. Seasonal variation in weight and biochemical composition of Chiridius armatus (Copepoda), Boreomysis arctica (Mysidacea) and Eukrohnia hamata (Chaetognatha) in relation to their biology. Sarsia 63: 145-154

Battle, H. I. (1934). Temperature and 'clearing' time for the sardine. Biol. Bd Can., Prog. Rept 11: 14-16

Bigelow, H. B. (1924). Plankton of the offshore waters of the Gulf of Maine. Bull. U.S. Bur. Fish. 40: 1-509

Conover, R. J. (1978). Transformation of organic matter. In: Kinne, O. (ed.) Marine ecology, Vol. IV, Dynamics. Wiley, Chichester, pp. 221-499

Dunbar, M. J. (1962). The life cycle of Sagitta elegans in arctic and subarctic seas, and the modifying effects of hydrographic differences in the environment. J. mar. Res. 20: $76-91$

Durbin, E. G., Durbin, A. G. (1978). Length and weight relationships of Acartia clausi from Narragansett Bay, R. I. Limnol. Oceanogr, 23: 958-969

Fänge, R., Grove, D. (1979). Digestion. In: Hoar, W. S., Randall, D. J., Brett, J. R. (eds) Fish physiology, Vol. 8. Academic Press, New York, pp. 161-260

Feigenbaum, D. (1979). Daily ration and specific daily ration of the chaetognath Sagitta enflata. Mar. Biol. 54:75-82

Feigenbaum, D. (MS 1979). Low temperature feeding by the chaetognath, Sagitta elegans, in Vinyard Sound, Massachusetts. Annu. Mtg. Am. Soc. Limnol. Oceanogr Abstr. (unpubl.)

Fox, L. R. (1975). Cannibalism in natural populations. In: Johnston, R. F., Frank, P. W., Michener, C. D. (eds) Ann. Rev. Ecol. Systematics 6. Annual Reviews, Inc., Palo Alto, pp. $87-106$

Harding, G., Vass, P., Pearre, S. (1980). Seasonal abundance, biomass, lipid content, size composition, and mean size of plankton. p. 23-34. In: Physical oceanography, dissolved nutrients, phytoplankton production, plankton biomass and sedimentation in St. Georges Bay, N.S., 1977. Can. Tech. Rep. Fish. Aquat. Sci. 934: pp. 1-162

Jobling, M. Davies, P. S. (1979). Gastric evacuation in plaice, Pleuronectes platessa L.: Effects of temperature and meal size. J. Fish Biol. 14: 539-546

Johansen, P. L. (1976). A study of tintinnids and other protozoa in the eastern Canadian waters with special reference to tintinnid feeding, nitrogen excretion and reproduction rates. Ph. D. thesis, Dalhousie Univ., Canada

Krauel, D. P. (1969). Bedford Basin data report 1967. Fish. Res. Bd Can., Tech. Rep. 120: 1-84

Kuhlmann, D. (1976). Laboratory studies on the feeding behavior of the chaetognaths Sagitta setosa J. Mueller and $S$. elegans Verrill with special reference to fish eggs and larvae as food organisms. Meeresforsch. 25: 163-171

Laurence, G. C. (1976). Calorific values of soma North Atlantic calanoid copepods. Fish. Bull U.S. 74: 218-220

Lubny-Gertsyk, Ye. A. (1953). Weight characteristics of the main forms of zooplankton in the Okhotsk and Bering Seas (Russ.) Dokl. Akad. Nauk. SSSR 91: 949-952

McLaren, I. A. (1969). Population and production ecology of zooplankton in Ogac Lake, a landlocked fiord in Baffin Island. J. Fish. Res. Bd Can. 26: 1485-1559

Matthews, J. B. L., Hestad, L. (1977). Ecological studies on the deep-water pelagic community of Korsfjorden, western Norway. Length/weight relationships for some macroplankton organisms. Sarsia 63: 57-63
Mayzaud, P., Taguchi, S. (1979). Spectral and biochemical characteristics of the particulate matter in Bedford Basm. J. Fish. Res. Bd Can. 36: 211-218

Mironov, G. N. (1960). Feeding of plankton predators II. Feeding of Sagitta (Russ.). Trudy sevastropol biol. Sta. 13: $78-88$

Nakai, Z. (1955). The chemical composition, volume, weight. and size of the important marine plankton. Spec. Pub. Tokai Fish Res. Lab. 5: 12-24

Omori, M. (1969). Weight and chemical composition of some important oceanic zooplankton in the North Pacific Ocean. Mar Biol. 3: 4-10

Omori, M. (1970). Variations of length, weight, respiratory rate, and the chemical composition of Calanus cristatus in relation to food and feeding. In: Steele, J. H. (ed.) Marine food chains. Oliver and Boyd, Edinburgh, pp. 113-126

Orr, A. P. (1934). The weight and chemical composition of Euchaeta norvegica, Boeck. Proc. R. Soc. Edinburgh 54 : $51-55$

Ostapenya, A. P., Shushkina, E. A. (1971). Caloricity of net plankton and energy equivalents of the body mass of some tropical planktonic crustacea. In: Vinogradov, M. E. (ed.) Life activity of pelagic communities in the ocean tropics. P. P. Shirshov Inst. Oceanogr., Akad. Nauk. SSSR, I.P.S.T Cat. No. 600941 : 190-197

Paranjape, M. A. (1980). Occurrence and significance of resting cysts in a hyaline tintinnid, Helicostomella subulata (Ehre.) Jorgensen. J. exp. mar Biol. Ecol. 48: 23-33

Pavlova, E. V. (1967). Food utilization and energy conversion by Black Sea Cladocera populations. In: Structure and Dynamics of Aquatic Communities and Populations. Naukova Dumka, Kiev. Fish. Res. Bd Can. Transl. Serv. 974: 66-85

Pearre, S., Jr. (1970). Light responses and feeding behavior of Sagitta elegans Verrill. Ph. D. thesis, Dalhousie Univ., Canada

Pearre, S., Jr. (1973). Vertical migration and feeding in Sagitta elegans Verrill. Ecology 54: 300-314

Pearre, S., Jr. (1980 a). Feeding by Chaetognatha: the relation of prey size to predator size in several species. Mar. Ecol. Progr. Ser. 3: 125-134

Pearre, S., Jr. $(1980 \mathrm{~b})$. The copepod width-weight relation and its utility in food chain research. Can. J. Zool. 58: $1884-1891$

Petipa, T S. (1957). On the average weight of common forms of zooplankton in the Black Sea. Trudy sevastopol'. biol. Sta. 9: $39-57$

Pielou, E. C. (1969). An introduction to mathematical ecology, Wiley, New York

Platt, T., Irwin, B. (1968). Primary productivity measurements in St. Margaret's Bay, 1967. Fish. Res. Bd Can., Tech. Rep. 77: $1-68$

Razouls, S. (1977). Analyse pondérale, élémentaire et calorimétrique des stades juveniles de copépodes pélagiques au cours d'une année. J. exp. mar Biol. Ecol. 26: 265-273

Reeve, M. R. (1980). Comparative experimental studies on the feeding of chaetognaths and ctenophores. J. Plankton Res. 2: 381-393

Sameoto, D. D. (1971 a). Macrozooplankton biomass measurements in Bedford Basin, 1969-1971 Fish. Res. Bd Can., Tech. Rep. 282: 1-238

Sameoto, D. D. (1971 b). Life history, ecological production, and an empirical mathematical model of the population of Sagitta elegans in St. Margaret's Bay, Nova Scotia. J. Fish. Res. Bd Can. 28: 971-985

Sameoto, D. D. (1972). Yearly respiration rate and estimated 
energy budget for Sagutta elegans. J. Fish. Res. Bd Can. 29: $987-996$

Sameoto, D. D. (1973). Annual life cycle and production of the chaetognath Sagitta elegans in Bedford Basin. Nova Scotia. J. Fish. Res. Bd Can. 30: 333-344

Sokal, R. R., Rohlf, F. J. (1969). Biometry: The principles and practice of statistics in biological research, W. H. Freeman and Co., San Francisco

Steele, J. H., Mullin, M. M. (1977). Zooplankton dynamics. In: Goldberg, E. D., McCave, I. N., O'Brien, J. J., Steele, J. H. (eds) The sea, Vol. 6. Wiley, New York, pp. 857-889

Studenıkina, Ye. I., Cherepakhina, M. M. (1969). Average weight of the main forms of zooplankton in the Sea of Azov. Hydrobiol. J. 5: 74-76

Sullivan, B. K. (1980). In situ feeding behavior of Sagitta elegans and Eukrohnia hamata (Chaetognatha) in relation to the vertical distribution and abundance of prey at Ocean Station 'P' Limnol. Oceanogr 25: 317-326

Szyper, J. P. (1978). Feeding rate of the chaetognath Sagitta enflata in nature. Estuar. \& coast. mar. Sci. 7: 567-575

Tyler, A. V (1973). Calorific values of some North Atlantic invertebrates. Mar. Biol. 19: 256-261

Wiebe, P. H., Boyd, S., Cox, J. L. (1975). Relationships between displacement volume, wet weight, dry weight, and carbon. Fish. Bull. U.S. 73: 777-786

Zo, Z. (1969). Observations on the natural populations of Sagitta elegans in Bedford Basin, Nova Scotia. M. Sc. thesis, Dalhousie Univ., Canada

Zo, Z. (1973). Breeding and growth of the chaetognath Sagitta elegans in Bedford Basin. Limnol. Oceanogr. 18: 750-756

This paper was presented by Professor P. J. Wangersky; it was accepted for printing on February 17, 1981 